\title{
Article \\ Effect of Tillage Technology Systems for Seed Germination Rate in a Laboratory Tests
}

\author{
Jan Winkler ${ }^{1}$, Tomáš Kopta ${ }^{2}$ (D), Vojtěch Ferby ${ }^{2}$, Lubomír Neudert ${ }^{3}$ and Magdalena Daria Vaverková ${ }^{4,5, *(1)}$ \\ 1 Department of Plant Biology, Faculty of AgriSciences, Mendel University in Brno, Zemědělská 1, \\ 61300 Brno, Czech Republic; jan.winkler@mendelu.cz \\ 2 Department of Vegetable Growing and Floriculture, Faculty of Horticulture, Mendel University in Brno, \\ 69144 Lednice, Czech Republic; tomas.kopta@mendelu.cz (T.K.); vojtech.ferby@mendelu.cz (V.F.) \\ 3 Department of Agrosystems and Bioclimatology, Faculty of AgriSciences, Mendel University in Brno, \\ Zemědělská 1, 61300 Brno, Czech Republic; lubomir.neudert@mendelu.cz \\ 4 Department of Applied and Landscape Ecology, Faculty of AgriSciences, Mendel University in Brno, \\ Zemědělská 1, 61300 Brno, Czech Republic \\ 5 Institute of Civil Engineering, Warsaw University of Life Sciences-SGGW, Nowoursynowska 159, \\ 02776 Warsaw, Poland \\ * Correspondence: magdalena.vaverkova@mendelu.cz
}

Citation: Winkler, J.; Kopta, T.; Ferby, V.; Neudert, L.; Vaverková, M.D. Effect of Tillage Technology Systems for Seed Germination Rate in a Laboratory Tests. Environments 2022, 9, 13. https://doi.org/10.3390/ environments 9020013

Academic Editor: Helvi

Heinonen-Tanski

Received: 15 November 2021

Accepted: 17 January 2022

Published: 19 January 2022

Publisher's Note: MDPI stays neutral with regard to jurisdictional claims in published maps and institutional affiliations.

Copyright: () 2022 by the authors. Licensee MDPI, Basel, Switzerland. This article is an open access article distributed under the terms and conditions of the Creative Commons Attribution (CC BY) license (https:// creativecommons.org/licenses/by/ $4.0 /)$.

\begin{abstract}
Reduced and soil-protective tillage technologies may represent certain negatives for cultivated crops associated with the biomass of mulch from intermediate crops and post-harvest residues. Sown crops, as well as field weeds, are exposed to impaired soil conditions. Soil conditions were assessed using biological tests. Eight plant species were chosen for the tests. Germination of tested plant species took place in controlled conditions in climaboxes. Seeds on Petri dishes were watered with soil leachates from three variants of tillage (Conventional, Minimum tillage, Direct sowing). Soil samples were collected from a 15-year field experiment. The soil leachates inhibited the germination rate of the chosen plant species. In the first term, all species exhibited a lower germination capacity in variants watered with the soil leachate. The reduced tillage technologies can apparently significantly slow down the germination rate in field crops and vegetables. Simple biological tests have the potential to assess the condition of arable soils.
\end{abstract}

Keywords: soil condition; biological tests; tillage

\section{Introduction}

Plants growing together on a site can support one another in their growth, but they can also compete or affect one another through allelopathy. The action of allelopathic substances may show even in the subsequently grown crops [1]. Allelopathy is defined as the acting of one plant on another by means of chemical compounds released into the surroundings [2-4]. Thus, allelopathy plays an important role in agriculture for selecting preceding crop, method of tillage and stand establishment [5]. Moreover, crop development is affected by allelopathy from certain weed species [6]. Alsaadawi et al. [7] inform us that incorporating post-harvest residues of sunflower into the soil and subsequent growing of beans led to the efficient suppression of weeds, thus allowing a significant reduction of herbicides. According to TeKrony et al. [8], due attention must be given to the effects of allelopathy particularly at establishing maize stands. Allelopathy shows in the impaired germination capacity of maize [9], which results in stand gaps and hence in the reduced yield [10,11]; this also applies to yields of other crops [12].

Tillage technologies referred to as reduced or soil-protecting leave the post-harvest residues of crops on the ground surface or are incorporated only to a shallow depth under the soil surface. Decaying plant residues can influence following crops or the growth of weeds; this is a certain risk which is considerably higher in these technologies [13,14]. 
Tisdall [15] claims that if straw and post-harvest residues are left on the soil surface or are accumulated in clumps, fungi and fungal organisms develop [16,17]. At the same time, the decomposition of organic substances changes soil chemical properties, particularly contents of nitrogen, carbon, and soil pH [15,18-20]. According to Marendiak et al. [21], nitrogen is mobilized by microorganisms during the decomposition of straw, which negatively affects the growth of sown crops. Ocio et al. [22], Hao et al. [23], Ning et al. [24] and Liu et al. [25] found out that straw incorporation into the soil by ploughing leads to the increased biomass of microorganisms. Marendiak et al. [21] arrived at similar conclusions and pointed out that the straw incorporation into the soil is beneficial, namely for the development of cellulolytic microflora. Some authors suggest that negative yield responses due to mulching with plant residues are due to nitrogen immobilization [26]. According to Baeumer and Bakermans [27], the use of no-tillage technologies results in the increased concentrations of phosphorus, potassium, and nitrogen in the upper soil layer. Moreover, no-till leads to a significant increase in acid phosphatase activity, promotes the formation of soil aggregates and improves their stability due to the presence of high crop residue and increased soil organic matter in the topsoil [28].

The reduced and soil-protecting technologies may show certain negatives associated with the biomass of mulch from intermediate crops and post-harvest residues. The sown plants are exposed to effects of allelopathy, to changes in the content of soil moisture, in the content of nutrients, decreased heat flux and development of microorganisms [5,26].

Soil environment is a dynamic complex of living and inanimate nature and processes occurring among the individual components. This complex is considerably affected by tillage systems which alter the conditions for the germination of crops, but also weeds, too. Therefore, the following hypothesis was set up: reduced tillage technologies alter the soil environment and create unfavourable phytotoxic conditions for the germination of plant seeds. Partial goals set up to confirm or refute the hypothesis were as follows: (i) to determine the effect of soil leachate on the germination capacity of the selected plant species, (ii) to determine the effect of soil leachate on the dynamics of plants species germination capacity, and (iii) to define seed germination trends in the selected groups of crops under the effect of soil leachates.

\section{Materials and Methods}

\subsection{Characteristics of Locality and Field Experiment}

The long-term field experiment was established in the autumn of 2003 at the field experimental station in Žabčice (Mendel University in Brno). The locality is situated between the villages of Žabčice and Židlochovice (South Moravian Region, Czech Republic $(\mathrm{CR}) ; 49.0237689 \mathrm{~N}, 16.6143786 \mathrm{E})$. The plot is in a flat terrain at an altitude of $179 \mathrm{~m}$ a.s.l. The long-term mean annual temperature is $9.2^{\circ} \mathrm{C}$ and the long-term total annual precipitation amount is $481 \mathrm{~mm}$. The soil type in the locality is Gleyic Fluvisol, which developed on the adjacent Svratka River alluvial sediments. In terms of structure, it is a clay-loam soil (heavy to very heavy). The acidity of soils is neutral ( $\mathrm{pH}$ 6.9) with a medium content of humus of $2.28 \%$. Nutrients available to the grown crops are at a sufficient level, and the base-exchange complex is well saturated too.

In the field experiment, three variants of tillage technologies were applied within a seven-plot crop rotation. The size of individual plots was $100 \mathrm{~m} \times 10 \mathrm{~m}\left(1000 \mathrm{~m}^{2}\right)$; the plots were organized into long blocks. In the technologies of growing the crops, common industrial fertilizers and pesticides were used, registered for the conditions of conventional agriculture in the CR. The rotation of crops was organized as follows: alfalfa-1st utility year, alfalfa-2nd utility year, winter wheat, maize (for silage), winter wheat, sugar beet, spring barley. Continuous variants of tillage technologies used for the grown crops were as follows: 
(i) Conventional tillage with ploughing (CT) - after the harvest of the preceding crop, ploughing to a depth of $0.20-0.24 \mathrm{~m}$ followed (medium deep) by the swivelling reversible Lemken plough. In the spring period, a sowing followed using the Accord seeding combination.

(ii) Minimum tillage (MT) - the harvest of preceding crop was followed by the shallow tillage using a chisel-type soil loosener Kverneland to a depth of $0.10 \mathrm{~m}$, after which a sowing followed in spring using the Accord seeding combination.

(iii) Direct sowing (NT) - the soil surface was not treated after the harvest of the preceding crop and am Accord seeding combination was used for sowing. Pre-sowing soil preparation for seeding depth was made only in maize and sugar beet.

\subsection{Methodology of Soil Sampling and Preparation of Soil Leachates}

Soil samples from three tillage variants in the field experiment, i.e., after 15 years of the action of technologies, were sampled in 2018 after the harvest of spring barley. In each variant, 8 sampling points were marked, at which 5 partial samples were collected from a depth of $0.15 \mathrm{~m}$ using the soil probing rod. The collected partial soil samples were mixed, homogenized, and a mixed sample was created. Mixed soil samples were spread in a thin layer. The drying was performed for 7 days at room temperature. Then, the samples were stored.

Prior to starting the laboratory experiment, $20 \mathrm{~g}$ of soil was weighed from each mixed sample from each tillage variant in 8 repetitions. The weighed amount of soil was mixed with $50 \mathrm{~mL}$ of distilled water in plastic bottles and left in the shaker for $2 \mathrm{~h}$. After a thorough shaking, the content of bottles was filtered on the filter paper. The obtained leachate was then used to water the seeds of selected plant species.

\subsection{Methodology of Laboratory Experiments with Germination}

There were eight plant species used in the laboratory experiment. The tested species included representatives of field crops (Triticum aestivum L., Hordeum vulgare L.), intermediate crops (Sinapis alba L., Phacelia tanacetifolia Benth.), vegetables (Allium cepa L., Lactuca sativa L.) and field weeds (Tripleurospermum inodorum/L./Sch.Bip., Galium aparine L.).

The experiment with the seed germination rate of selected plant species took place in climaboxes with a light regime of $12 \mathrm{~h}$ dark $/ 12 \mathrm{~h}$ light at an air temperature of $15^{\circ} \mathrm{C}$. The seeds germinated in Petri dishes; each dish contained 8 seeds on 3 layers of filter paper. Seeds on the Petri dishes were watered with soil leachates from the three variants of tillage (CT, MT, NT) and with tap water (Control). Each variant of tillage and plant species had 8 repetitions, and each repetition had a separate Petri dish. The germination of seeds was assessed in 4 terms. The first term (I) was Day 3 from the establishment of the experiment; the second term (II) was Day 7, the third term (III) was Day 14, and the fourth term (IV) was Day 21 from the establishment of the experiment. During the experiment, the Petri dishes were evenly watered.

Germination was assessed for each plant species separately. All data were subjected to tests of homogenity and normality. The results were statistically evaluated by the multifactor ANOVA and by the Fischer LSD test. The data were not transformed prior to the statistical analysis.

\section{Results}

The germination capacity of caryopses of field crops Triticum aestivum and Hordeum vulgare was the lowest in the variant watered with the NT systems leachate in the first term of assessment (Day 3 from the establishment of the experiment). In the other terms, the germination capacity was gradually becoming equal, and in the third and fourth term, differences were no more statistically significant (Figures 1 and 2). 


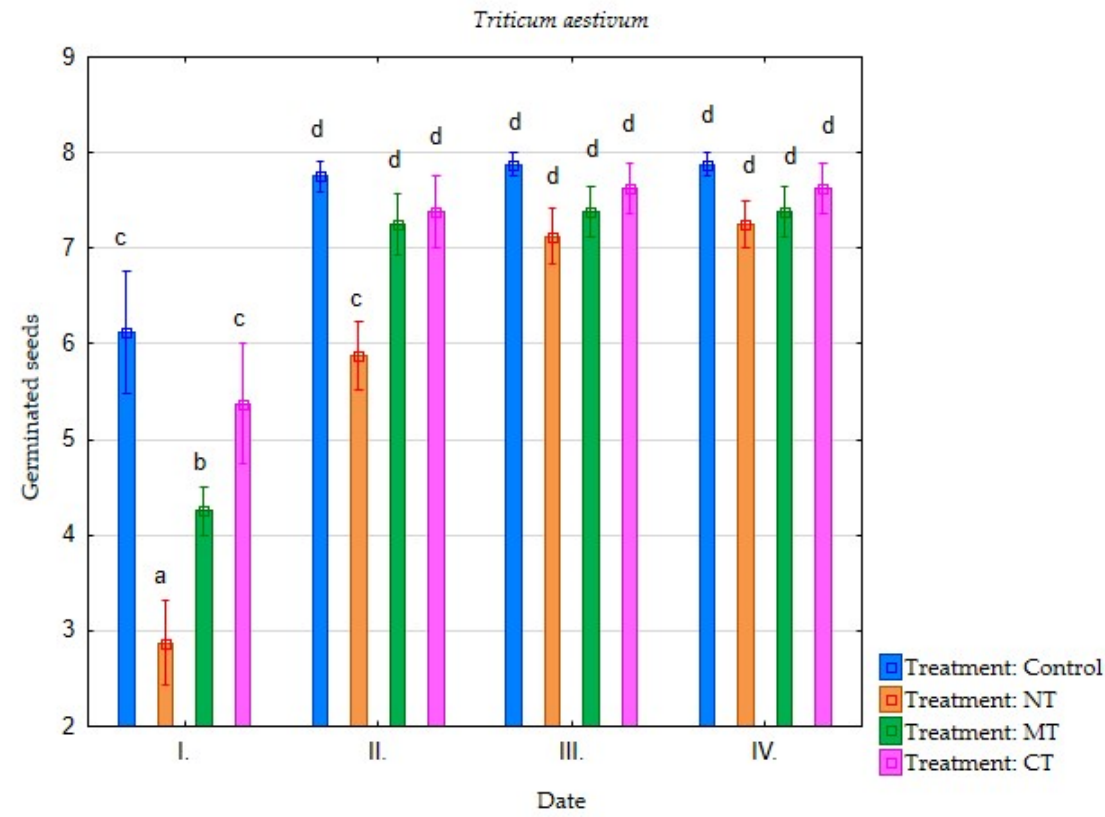

Figure 1. Development of the germination of Triticum aestivum caryopses watered with soil leachates from different soil tillage. The results represent the mean of 8 biological replicates \pm SE. Identical letters express statistical non-significance between the variants, different letters express statistical significance at a significance level $p=0.05$ (Fisher LSD test). The plot shows the mean, the whiskers representing the standard error, values with different letter $(a, b, c, d)$ differ significantly. Variants of tillage technologies: CT—Conventional tillage with ploughing; MT-Minimum tillagethe; NTDirect sowing.

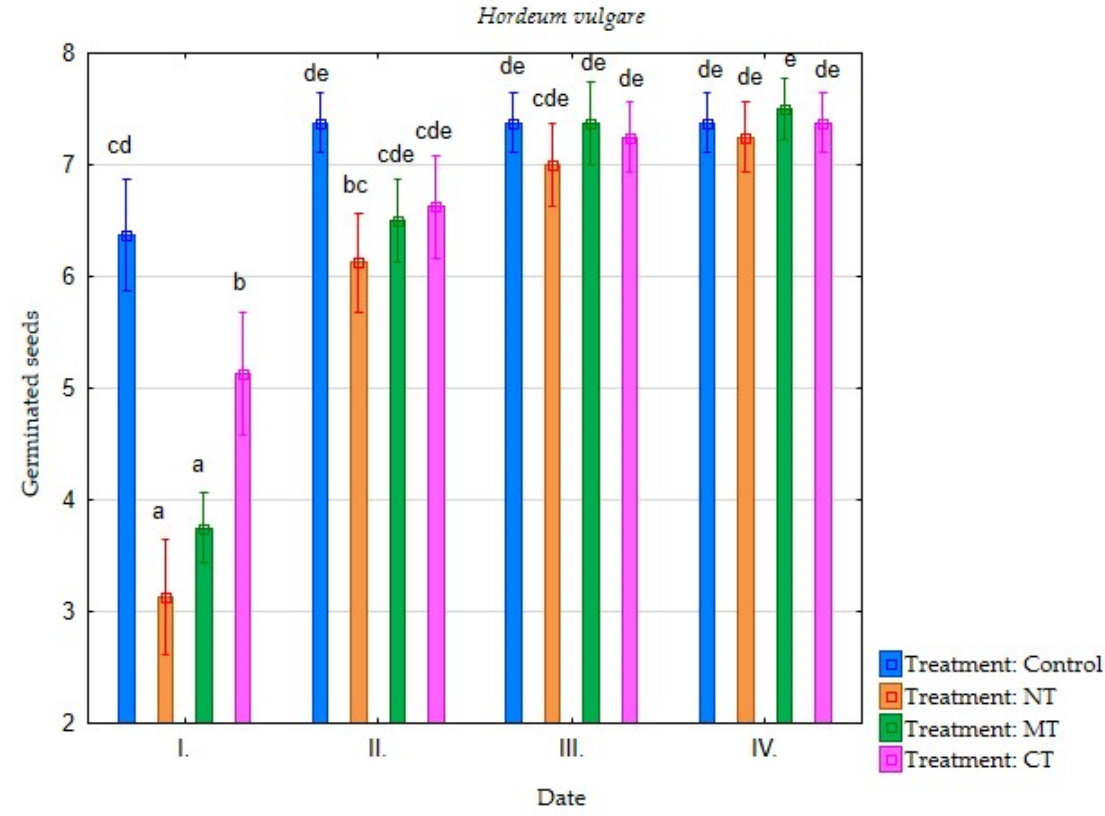

Figure 2. Development of the germination of Hordeum vulgare caryopses watered with soil leachates from different soil tillage. The results represent the mean of 8 biological replicates \pm SE. Identical letters express statistical non-significance between the variants, different letters express statistical significance at a significance level $p=0.05$ (Fisher LSD test). The plot shows the mean, the whiskers representing the standard error, values with different letter $(a, b, c, d, e)$ differ significantly. Variants of tillage technologies: CT-Conventional tillage with ploughing; MT-Minimum tillagethe; NTDirect sowing. 
The germination response of crops used as intermediate crops (Sinapis alba, Phacelia tanacetifolia) was similar. The lowest one was recorded in the variant watered with NT and MT leachates in the first term of assessment (Day 3 from the establishment of the experiment). In the following terms (II, III, IV), the germination capacity reached similar values with differences not being statistically significant (Figures 3 and 4).

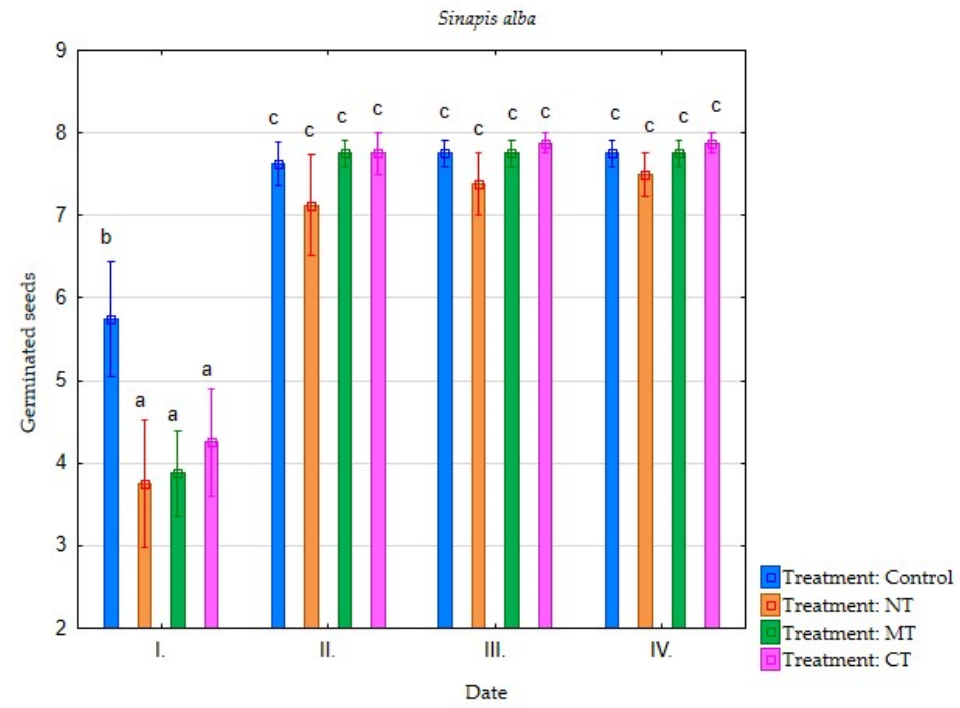

Figure 3. Development of the germination of Sinapis alba caryopses watered with soil leachates from different soil tillage. The results represent the mean of 8 biological replicates \pm SE. Identical letters express statistical non-significance between the variants, different letters express statistical significance at a significance level $p=0.05$ (Fisher LSD test). The plot shows the mean, the whiskers representing the standard error, values with different letter $(a, b, c)$ differ significantly. Variants of tillage technologies: CT—Conventional tillage with ploughing; MT—Minimum tillagethe; NTDirect sowing.

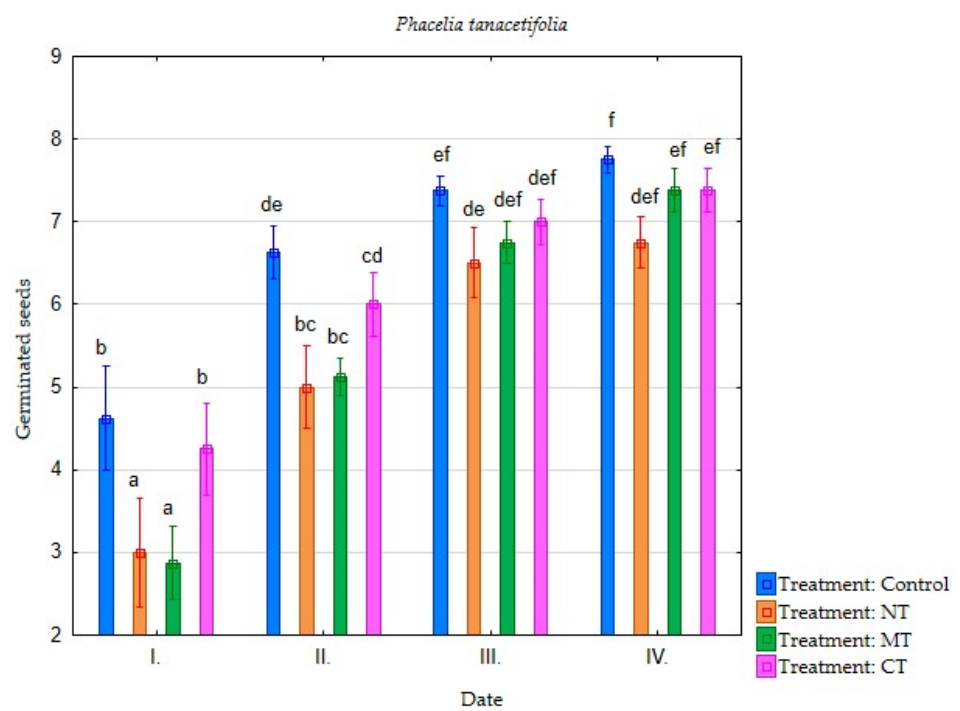

Figure 4. Development of the germination of Phacelia tanacetifolia caryopses watered with soil leachates from different soil tillage. The results represent the mean of 8 biological replicates \pm SE. Identical letters express statistical non-significance between the variants, different letters express statistical significance at a significance level $p=0.05$ (Fisher LSD test). The plot shows the mean, the whiskers representing the standard error, values with different letter ( $a, b, c, d, e, f)$ differ significantly. Variants of tillage technologies: CT-Conventional tillage with ploughing; MT-Minimum tillagethe; NT-Direct sowing. 
The most pronounced reaction was recorded in the germination capacity of seeds vegetables (Allium cepa, Lactuca sativa). Soil leachates from the variants of reduced tillage (NT and MT) exhibited a lower germination capacity in the first term of assessment. In the last term of assessment, this difference was no more statistically significant. The soil leachates obviously inhibit the process of germination (Figures 5 and 6).

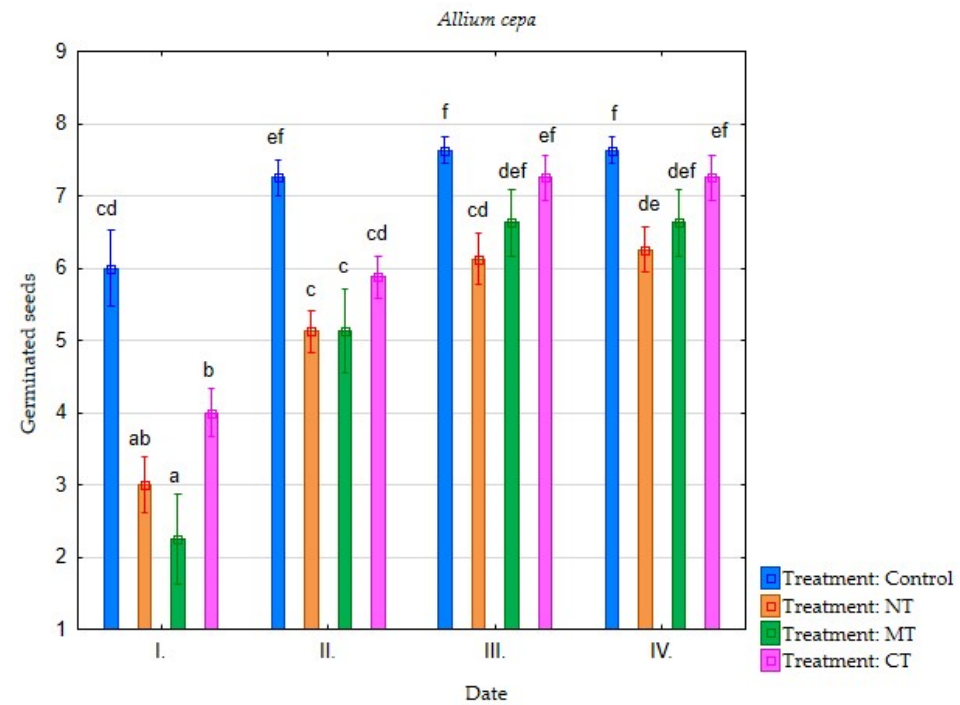

Figure 5. Development of the germination of Allium cepa caryopses watered with soil leachates from different soil tillage. The results represent the mean of 8 biological replicates $\pm \mathrm{SE}$. Identical letters express statistical non-significance between the variants, different letters express statistical significance at a significance level $p=0.05$ (Fisher LSD test). The plot shows the mean, the whiskers representing the standard error, values with different letter $(a, b, c, d, e, f)$ differ significantly. Variants of tillage technologies: CT-Conventional tillage with ploughing; MT-Minimum tillagethe; NTDirect sowing.

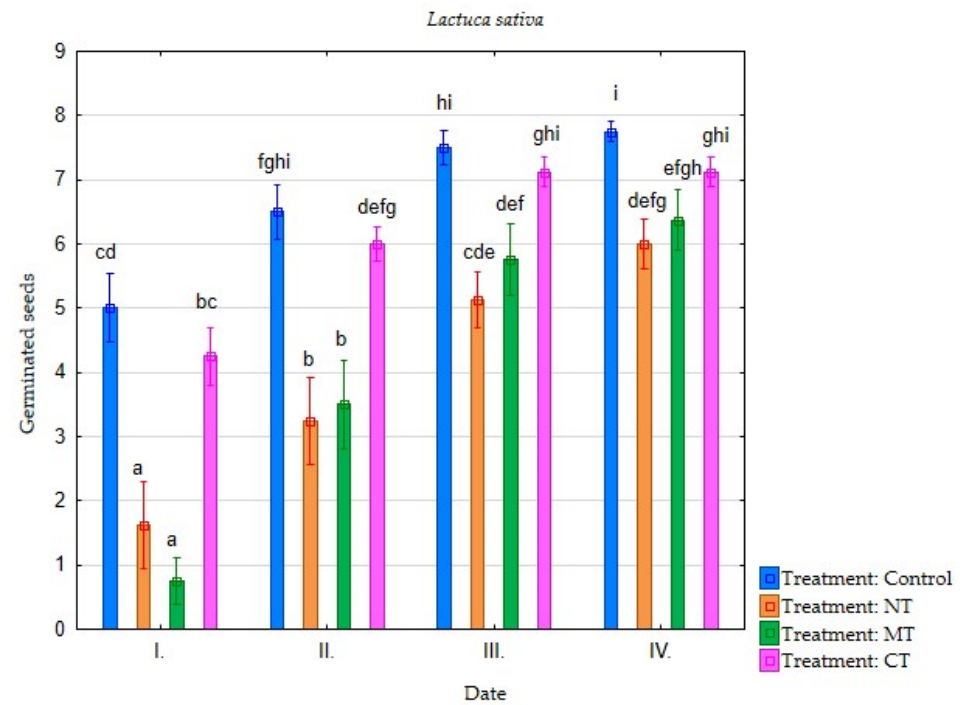

Figure 6. Development of the germination of Lactuca sativa caryopses watered with soil leachates from different soil tillage. The results represent the mean of 8 biological replicates $\pm \mathrm{SE}$. Identical letters express statistical non-significance between the variants, different letters express statistical significance at a significance level $p=0.05$ (Fisher LSD test). The plot shows the mean, the whiskers representing the standard error, values with different letter $(a, b, c, d, e, f, g, h, i)$ differ significantly. Variants of tillage technologies: CT—Conventional tillage with ploughing; MT-Minimum tillagethe; NT-Direct sowing. 
Compared with the cultural plant species, the germination of two weeds (Tripleurospermum inodorum, Galium aparine) was markedly differed. Significant differences in seed germination rate were between the terms of assessment. Germination was clearly lower in the first term of assessment. Higher germination was recorded in the variants with soil leachates from reduced variants of tillage (NT and MT); lower germination was observed in the leachate from the variant with the CT. The differences in germination observed for the variants with leachate were not statistically significant (Figures 7 and 8).

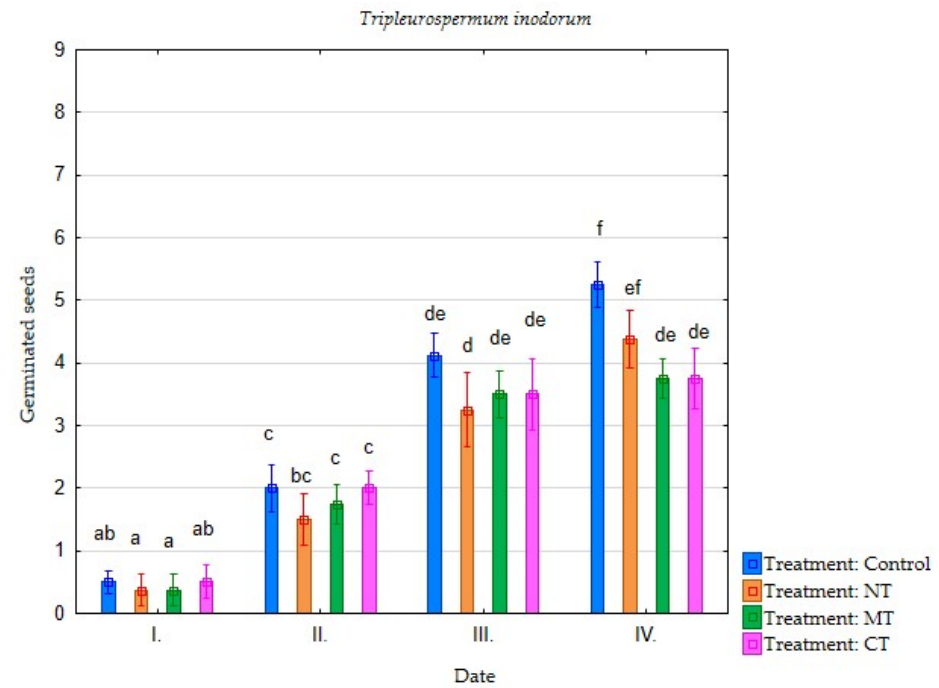

Figure 7. Development of the germination of Tripleurospermum inodorum caryopses watered with soil leachates from different soil tillage. The results represent the mean of 8 biological replicates $\pm \mathrm{SE}$. Identical letters express statistical non-significance between the variants, different letters express statistical significance at a significance level $p=0.05$ (Fisher LSD test). The plot shows the mean, the whiskers representing the standard error, values with different letter $(a, b, c, d, e, f)$ differ significantly. Variants of tillage technologies: CT - Conventional tillage with ploughing; MT-Minimum tillagethe; NT-Direct sowing.

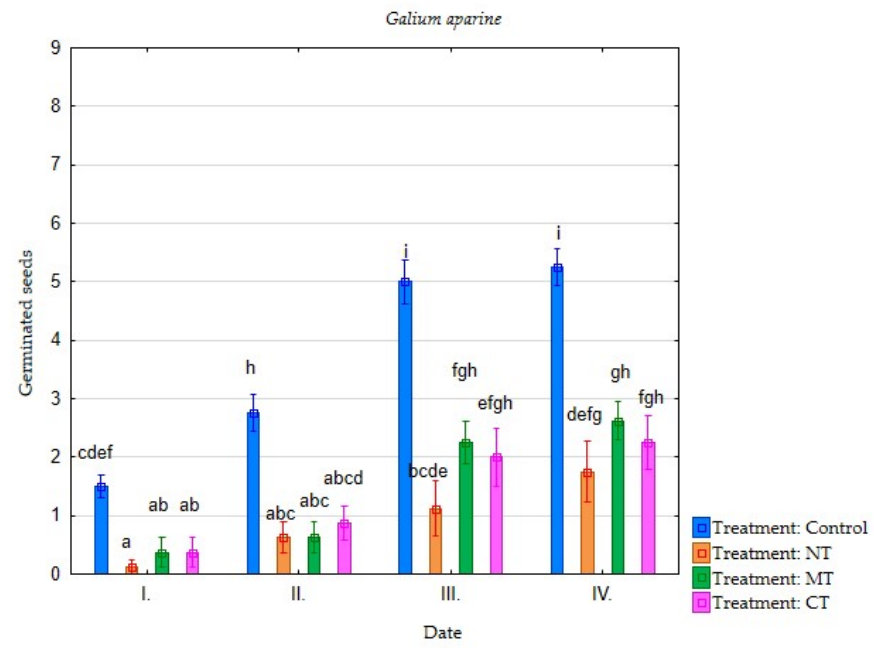

Figure 8. Development of the germination of Galium aparine caryopses watered with soil leachates from different soil tillage. The results represent the mean of 8 biological replicates \pm SE. Identical letters express statistical non-significance between the variants, different letters express statistical significance at a significance level $p=0.05$ (Fisher LSD test). The plot shows the mean, the whiskers representing the standard error, values with different letter $(a, b, c, d, e, f, g, h, i)$ differ significantly. Variants of tillage technologies: CT—Conventional tillage with ploughing; MT-Minimum tillagethe; NT-Direct sowing. 
Germination of seeds results of individual selected plant species are presented in Table 1. It follows from them that the germination response is different in them. The highest germination capacity was exhibited by the control variant in which only water was used for irrigation. The other experimental variants with the soil leachates showed different effects on the germination capacity of selected plant species.

Table 1. Average germination of studied plant species.

\begin{tabular}{|c|c|c|c|c|c|c|c|c|c|}
\hline \multirow{2}{*}{$\begin{array}{l}\text { Irrigation } \\
\text { with Soil } \\
\text { Leachate }\end{array}$} & \multirow{2}{*}{$\begin{array}{c}\text { Terms of } \\
\text { Evaluation } \\
\text { (Date) }\end{array}$} & \multicolumn{8}{|c|}{ Average Germination of Selected Plant Species (Number of Germinated Seeds) } \\
\hline & & $\begin{array}{l}\text { Triticum } \\
\text { aestivum }\end{array}$ & $\begin{array}{l}\text { Hordeum } \\
\text { vulgare }\end{array}$ & $\begin{array}{l}\text { Sinapis } \\
\text { alba }\end{array}$ & $\begin{array}{c}\text { Phacelia } \\
\text { tanacetifolia }\end{array}$ & $\begin{array}{l}\text { Allium } \\
\text { cepa }\end{array}$ & $\begin{array}{l}\text { Lactuca } \\
\text { sativa }\end{array}$ & $\begin{array}{c}\text { Tripleurospermum } \\
\text { inodorum }\end{array}$ & $\begin{array}{l}\text { Galium } \\
\text { aparine }\end{array}$ \\
\hline \multirow{4}{*}{$\begin{array}{l}\text { Minimum } \\
\text { tillage (MT) }\end{array}$} & I. & 4.25 & 3.75 & 3.88 & 2.88 & 2.25 & 0.75 & 0.38 & 0.38 \\
\hline & II. & 7.25 & 6.50 & 7.75 & 5.13 & 5.13 & 3.50 & 1.75 & 0.63 \\
\hline & III. & 7.38 & 7.38 & 7.75 & 6.75 & 6.63 & 5.75 & 3.50 & 2.25 \\
\hline & IV. & 7.38 & 7.50 & 7.75 & 7.38 & 6.63 & 6.38 & 3.75 & 2.63 \\
\hline \multirow{4}{*}{$\begin{array}{c}\text { Direct } \\
\text { sowing } \\
(\mathrm{NT})\end{array}$} & I. & 2.88 & 3.13 & 3.75 & 3.00 & 3.00 & 1.63 & 0.38 & 0.13 \\
\hline & II. & 5.88 & 6.13 & 7.13 & 5.00 & 5.13 & 3.25 & 1.50 & 0.63 \\
\hline & III. & 7.13 & 7.00 & 7.38 & 6.50 & 6.13 & 5.13 & 3.25 & 1.13 \\
\hline & IV. & 7.25 & 7.25 & 7.50 & 6.75 & 6.25 & 6.00 & 4.38 & 1.75 \\
\hline \multirow{4}{*}{$\begin{array}{l}\text { Conventional } \\
\text { tillage } \mathrm{CT} \text { ) }\end{array}$} & I. & 5.38 & 5.13 & 4.25 & 4.25 & 4.00 & 4.25 & 0.50 & 0.38 \\
\hline & II. & 7.38 & 6.63 & 7.75 & 6.00 & 5.88 & 6.00 & 2.00 & 0.88 \\
\hline & III. & 7.63 & 7.25 & 7.88 & 7.00 & 7.25 & 7.13 & 3.50 & 2.00 \\
\hline & IV. & 7.63 & 7.38 & 7.88 & 7.38 & 7.25 & 7.13 & 3.75 & 2.25 \\
\hline \multirow{4}{*}{$\begin{array}{l}\text { Water } \\
\text { (Control) }\end{array}$} & I. & 6.13 & 6.38 & 5.75 & 4.63 & 6.00 & 5.00 & 0.50 & 1.50 \\
\hline & II. & 7.75 & 7.38 & 7.63 & 6.63 & 7.25 & 6.50 & 2.00 & 2.75 \\
\hline & III. & 7.88 & 7.38 & 7.75 & 7.38 & 7.63 & 7.50 & 4.13 & 5.00 \\
\hline & IV. & 7.88 & 7.38 & 7.75 & 7.75 & 7.63 & 7.75 & 5.25 & 5.25 \\
\hline
\end{tabular}

From the summary of the analysis of variance (Table 2), it is obvious that the effect of evaluation time (I-IV) on seed germination was strongest for all tested species. Overall effect of different soil leachate (treatment) on seed germination was statistically significant in all species except Sinapis alba and Tripleurospermum inodorum.

Table 2. Summary of analysis of variance for germination of selected species according to treatment and time of assessment.

\begin{tabular}{|c|c|c|c|c|c|c|c|c|}
\hline Source of Variance & $\begin{array}{l}\text { Triticum } \\
\text { aestivum }\end{array}$ & $\begin{array}{l}\text { Hordeum } \\
\text { vulgare }\end{array}$ & $\begin{array}{l}\text { Sinapis } \\
\text { alba }\end{array}$ & $\begin{array}{c}\text { Phacelia } \\
\text { tanacetifolia }\end{array}$ & $\begin{array}{c}\text { Allium } \\
\text { cepa }\end{array}$ & $\begin{array}{l}\text { Lactuca } \\
\text { sativa }\end{array}$ & $\begin{array}{c}\text { Tripleurospermum } \\
\text { inodorum }\end{array}$ & $\begin{array}{l}\text { Galium } \\
\text { aparine }\end{array}$ \\
\hline Treatment & $* * *$ & $* * *$ & NS & $* * *$ & $* * *$ & $* * *$ & NS & $* * *$ \\
\hline Time of evaluation & $* * *$ & $* * *$ & $* * *$ & $* * *$ & $* * *$ & $* * *$ & $* * *$ & $* * *$ \\
\hline $\begin{array}{c}\text { Treatment } \times \text { time of } \\
\text { evaluation }\end{array}$ & * & * & NS & NS & NS & NS & NS & * \\
\hline
\end{tabular}

Differences in germination depending on treatment and time of evaluation and its interaction by ANOVA non-significant (NS) or significant at $p \leq 0.05\left(^{*}\right)$ or $p \leq 0.001\left(^{* * *}\right)$, respectively.

\section{Discussion}

Results of germination tests indicate that soil leachates inhibit the germination of most tested plant species as compared with the water. Thus, it can be assumed there are substances in the arable soils, which slow down the seed germination rate of field crops and vegetables, and even may induce dormancy in weeds. A precise identification and determination of inhibiting substances is very difficult. However, a degree of inhibition can be determined by simple biological tests of germination. Higher plants currently most used to evaluate the environment contamination are Allium cepa, Vicia faba, Zea mays, Tradescantia, Nicotiana tabacum, Crepis capillaris and Hordeum vulgare [29]. Very sensitive vegetable species are Allium cepa and Lactuca sativa $[29,30]$. The reaction of vegetable species was expressive and statistically significant especially in Lactuca sativa, which was in line with the findings of Mañas et al. [30]. Moreover, some studies recommended Lactuca sativa as a bioindicator to determine the toxicity of soil and water samples [31]. 
The results also indicate that the reduced technologies of tillage (NT and MT) slow down the germination of the seeds of studied species. This is obvious particularly in the first term of assessment. We can assume that in field conditions, the inhibition of germination rate can show as uneven and slowed-down emergence or in the development of some soil pathogens. According to Chovancová et al. [32], Małecka-Jankowiak et al. [33] and Mancinelli et al. [34], the system of tillage changes soil properties and thus affects the growth and development of plants. According to Wang et al. [35], despite the high potential of mulch, its effect for increasing yield would depend on the amount of precipitation during the crop growing season. As the composition of soil organisms changes due to the decomposition of post-harvest residues, applied pesticides and industrial fertilizers, the soil processes change too [36-39]. This may result in the development of inhibiting substances slowing down the process of germination, which is particularly obvious in the reduced technologies of tillage. The trend is evident namely in cereals (Triticum aestivum, Hordeum vulgare), i.e., in crops that are grown on the experimental plot. On the other hand, it is not so apparent in Sinapis alba and Phacelia tanacetifolia, which are not represented in the crop rotation. This shows that post-harvest residues of a certain crop in the soil inhibit (slow down) the germination of seeds of identical plant species.

A number of authors claim that the addition of extracts from different crops results in a slowed-down germination rate in maize $[9,10,26,40]$ and spring barley [41]. A cause in the decreased germination rate can be a change in the production of $\mathrm{H}_{2} \mathrm{O}_{2}$ due to the disturbed balance between phytohormones (abscisic acid and ethylene) in the seeds [42] by oxidation stress induced by phytotoxins from extracts, which cause damage to cells [43] and change in the mobilization of reserves as well as in the generation of energy during germination [44]. It follows out from the results that consequences of the action of biomass decay show also in the soil leachate.

The response of weed species (Tripleurospermum inodorum, Galium aparine) was different than that of cultural plants. Compared with the control variant, which was irrigated with water, soil leachates slowed down the germination of their seeds too. However, differences between the leachates from the variants of tillage technologies were no more statistically significant. Therefore, the germination of weed species is not affected by inhibitory substances in the soil environment. Although many authors point out the influence of technologies on the change in the infestation of field crops by weeds [45-47], our research results suggest that inhibitory substances in the soil environment should not be held responsible for that.

Thus, technologies of tillage change the soil environment; in reduced technologies, the action of inhibitory substances may show in the germination rate. Slowed-down germination can affect the quality of field crop and vegetable stands. Conventional tillage technology mitigates these negative consequences.

\section{Conclusions}

The research confirmed that the tillage systems change the soil environment. Soil leachates showed an inhibitory influence on the seed germination rate of selected plant species. In the first term of assessment, all plant species in variants watered with the soil leachate exhibited lower germination. The total number of germinated seeds did not differ, though. The soil environment has a potential to slow down germination, which can be a reason for uneven emergence in field crops. It is also obvious that reduced technologies of tillage can considerably slow down the germination rate in field crops. The phenomenon is more conspicuous in crops grown one after the other and with the use of reduced technologies. Results of our laboratory test show a great potential of biological methods. The complex of soil environment factors affecting the germination of seeds can be assessed comprehensively thanks to simple biological tests. The assessment of the combined effect of agrochemicals by means of biological tests appears very promising. The tests represent a low-cost, complex, and more applicable variant for evaluating the condition of agricultural soils. 
Results suggest that alternative methods of management, which reduce the amounts of agrochemicals on arable land and in substrates that are increasingly used for intensive production, should be given more attention. In this context, an issue comes to the fore of hydroponic growing of vegetables, where a rockwool growing medium is used as a substrate.

Author Contributions: Conceptualization, J.W. and T.K.; methodology, J.W., L.N. and T.K.; formal analysis, J.W. and T.K.; investigation, J.W.; resources, J.W., M.D.V., V.F. and T.K.; data curation, J.W., V.F. and T.K.; writing-original draft preparation, J.W., M.D.V., V.F. and T.K.; writing-review and editing, J.W., M.D.V. and T.K.; visualization, J.W., M.D.V. and T.K.; supervision, J.W., M.D.V. and T.K.; project administration, J.W. and T.K.; funding acquisition, M.D.V. All authors have read and agreed to the published version of the manuscript.

Funding: This research was funded by IGA-ZF/2021-SI1010 Ecologization of the hydroponic system of growing vegetables.

Institutional Review Board Statement: Not applicable.

Informed Consent Statement: Not applicable.

Data Availability Statement: Not applicable.

Conflicts of Interest: The authors declare no conflict of interest.

\section{References}

1. Mariotti, M.; Masoni, A.; Ercoli, L.; Arduini, I. Above- and below-ground competition between barley, wheat, lupin and vetch in a cereal and legume intercropping system. Grass Forage Sci. 2009, 64, 401-412. [CrossRef]

2. Rice, E.L. Allelopathy, 2nd ed.; Academic Press: Orlando, FL, USA, 2012; 368p.

3. Kato-Noguchi, H.; Kimura, F.; Ohno, O.; Suenaga, K. Involvement of allelopathy in inhibition of understory growth in red pine forests. J. Plant Physiol. 2017, 218, 66-73. [CrossRef]

4. Qin, F.; Liu, S.; Yu, S. Effects of allelopathy and competition for water and nutrients on survival and growth of tree species in Eucalyptus urophylla plantations. For. Ecol. Manag. 2018, 424, 387-395. [CrossRef]

5. Chon, S.U.; Nelson, C.J. Allelopathy in Compositae plants. A review. Agron. Sustain. Dev. 2010, 30, 349-358. [CrossRef]

6. Jabran, K.; Mahajan, G.; Sardana, V.; Chauhan, B.S. Allelopathy for weed control in agricultural systems. Crop Prot. 2015, 72, 57-65. [CrossRef]

7. Alsaadawi, I.S.; Khaliq, A.; Al-Temimi, A.A.; Matloob, A. Integration of sunflower (Helianthus annuus) residues with a pre-plant herbicide enhances weed suppression in broad bean (Vicia faba). Planta Daninha 2011, 29, 849-859. [CrossRef]

8. TeKrony, D.M.; Egli, D.B.; Wickham, D.A. Corn seed vigour effect on no-tillage field performance. I. Field emergence. Crop Sci. 1989, 29, 1523-1528. [CrossRef]

9. Wicks, G.A.; Crutchfield, D.A.; Burnside, O.C. Influence of wheat (Triticum aestivum) straw mulch and metolachlor on corn (Zea mays) growth and yield. Weed Sci. 1994, 42, 141-147. [CrossRef]

10. Ngetich, K.F.; Diels, J.; Shisanya, C.A.; Mugwe, J.N.; Mucherumuna, M.; Mugendi, D.N. Effects of selected soil and water conservation techniques on runoff, sediment yield and maize productivity under sub-humid and semi-arid conditions in Kenya. Catena 2014, 121, 288-296. [CrossRef]

11. Tuure, J.; Räsänen, M.; Hautala, M.; Pellikka, P.; Mäkelä, P.S.A.; Alakukku, L. Plant residue mulch increases measured and modelled soil moisture content in the effective root zone of maize in semi-arid Kenya. Soil Tillage Res. 2021, 209, 104945. [CrossRef]

12. Cook, H.F.; Valdes, G.S.B.; Lee, H.C. Mulch effects on rainfall interception, soil physical characteristics and temperature under Zea mays L. Soil Tillage Res. 2006, 91, 227-235. [CrossRef]

13. Alsaadawi, I.S. Allelopathic influence of decomposing wheat residues in agroecosystems. J. Crop Prod. 2001, 4, 185-196. [CrossRef]

14. Morris, N.L.; Miller, P.C.H.; Orson, J.H.; Froud-Williams, R.J. The effect of wheat straw residue on the mergence and early growth of sugar beet (Beta vulgaris) and oilseed rape (Brassica napus). Eur. J. Agron. 2009, 30, 151-162. [CrossRef]

15. Tisdall, J.M. Crop establishment a serious limitation to high productivity. Soil Tillage Res. 1996, 40, 1-2. [CrossRef]

16. Gu, S.; Wu, S.; Guan, Y.; Zhai, C.; Zhang, Y.; Bello, A.; Guo, X.; Yang, W. Arbuscular mycorrhizal fungal community was affected by tillage practices rather than residue management in black soil of northeast China. Soil Tillage Res. 2020, 198, 104552. [CrossRef]

17. Matrose, N.A.; Obikeze, K.; Belay, Z.A.; Caleb, O.J. Plant extracts and other natural compounds as alternatives for post-harvest management of fruit fungal pathogens: A review. Food Biosci. 2021, 41, 100840. [CrossRef]

18. Han, M.; Sun, L.; Gan, D.; Fu, L.; Zhu, B. Root functional traits are key determinants of the rhizosphere effect on soil organic matter decomposition across 14 temperate hardwood species. Soil Biol. Biochem. 2020, 151, 108019. [CrossRef]

19. Błońska, E.; Piaszczyk, W.; Staszel, K.; Lasota, J. Enzymatic activity of soils and soil organic matter stabilization as an effect of components released from the decomposition of litter. Appl. Soil Ecol. 2021, 157, 103723. [CrossRef] 
20. Zhao, Q.; Thompson, A.M.; Callister, S.J.; Tfaily, M.M.; Bell, S.L.; Hobbie, S.E.; Hofmockel, K.S. Dynamics of organic matter molecular composition under aerobic decomposition and their response to the nitrogen addition in grassland soils. Sci. Total Environ. 2022, 806, 150514. [CrossRef] [PubMed]

21. Marendiak, D.; Kopčanová, L.; Leitgeb, S. Pol'nohospodárska Mikrobiológia; Príroda: Bratislava, Slovakia, 1987; 444p. (In Slovak)

22. Ocio, J.A.; Brookes, P.C.; Jenkinson, D.S. Field incorporation of straw and its effects on soil microbial biomass and soil inorganic N. Soil Biol. Biochem. 1991, 23, 171-176. [CrossRef]

23. Hao, M.; Hu, H.; Liu, Z.; Dong, Q.; Sun, K.; Feng, Y.; Li, G.; Ning, T. Shifts in microbial community and carbon sequestration in farmland soil under long-term conservation tillage and straw returning. Appl. Soil Ecol. 2019, 136, 43-54. [CrossRef]

24. Ning, X.; Wang, X.; Guan, Z.; Gu, Y.; Wu, C.; Hu, W. Effects of different patterns of maize-straw application on soil microorganisms, enzyme activities, and grain yield. Bioengineered 2021, 12, 3684-3698. [CrossRef]

25. Liu, X.; Peng, C.; Zhang, W.; Li, S.; An, T.; Xu, Y.; Ge, Z.; Xie, N.; Wang, J. Subsoiling tillage with straw incorporation improves soil microbial community characteristics in the whole cultivated layers: A one-year study. Soil Tillage Res. 2022, 215 , 105188. [CrossRef]

26. Tuure, J.; Korpela, A.; Hautala, M.; Hakojärvi, M.; Mikkola, H.; Räsänen, M.; Duplissy, J.; Pellikka, P.; Petäjä, T.; Kulmala, M.; et al. Comparison of surface foil materials and dew collectors location in an arid area: A one-year field experiment in Kenya. Agric. For. Meteorol. 2019, 15, 276-277. [CrossRef]

27. Baeumer, K.; Bakermans, W.A.P. Zero-tillage. Adv. Agron. 1973, 25, 77-123.

28. Chellappa, J.; Sagar, K.L.; Sekaran, U.; Kumar, S.; Sharma, P. Soil organic carbon, aggregate stability and biochemical activity under tilled and no-tilled agroecosystems. J. Agric. Food Res. 2021, 4, 100139. [CrossRef]

29. Bonciu, E.; Firbas, P.; Fontanetti, C.S.; Wusheng, J.; Karaismailoğlu, M.C.; Liu, D.; Menicucci, F.; Pesnya, D.S.; Popescu, A.; Romanovsky, A.V.; et al. An evaluation for the standardization of the Allium cepa test as cytotoxicity and genotoxicity assay. Caryologia 2018, 71, 191-209. [CrossRef]

30. Mañas, P.; De las Heras, J. Phytotoxicity test applied to sewage sludge using Lactuca sativa L. and Lepidium sativum L. seeds. Int. J. Environ. Sci. Technol. 2018, 15, 273-280. [CrossRef]

31. Priac, A.; Badot, P.-M.; Crini, G. Treated wastewater phytotoxicity assessment using Lactuca sativa: Focus on germination and root elongation test parameters. Comptes Rendus Biol. 2017, 340, 188-194. [CrossRef]

32. Chovancova, S.; Illek, F.; Winkler, J. The effect of three tillage treatments on weed infestation in maize monoculture. Pak. J. Bot. 2020, 52, 697-701. [CrossRef]

33. Małecka-Jankowiak, I.; Blecharczyk, A.; Swedzrzynska, D.; Sawinska, Z.; Piechota, T. The effect of long-term tillage systems on some soil properties and yield of pea (Pisum sativum L.). Acta Sci. Pol. Agric. 2016, 15, 37-50.

34. Mancinelli, R.; Muleo, R.; Marinari, S.; Radicetti, E. How Soil Ecological Intensification by Means of Cover Crops Affects Nitrogen Use Effciency in Pepper Cultivation. Agriculture 2019, 9, 145. [CrossRef]

35. Wang, Y.; Xie, Z.; Malhi, S.S.; Vera, C.L.; Zhang, Y.; Wang, J. Effects of rainfall harvesting and mulching technologies on water use efficiency and crop yield in the semi-arid Loess Plateau, China. Agric. Water Manag. 2009, 96, 374-382. [CrossRef]

36. Geisseler, D.; Linquist, B.A.; Lazicki, P.A. Effect of fertilization on soil microorganisms in paddy rice systems-A meta-analysis Soil Biol. Biochem. 2017, 115, 452-460. [CrossRef]

37. Baćmaga, M.; Wyszkowska, J.; Kucharski, J. The influence of chlorothalonil on the activity of soil microorganisms and enzymes Ecotoxicology 2018, 27, 1188-1202. [CrossRef]

38. Ma, Q.; Wu, L.; Wang, J.; Ma, J.; Zheng, N.; Hill, P.W.; Chadwick, D.R.; Jones, D.L. Fertilizer regime changes the competitive uptake of organic nitrogen by wheat and soil microorganisms: An in-situ uptake test using 13C, 15N labelling, and 13C-PLFA analysis. Soil Biol. Biochem. 2018, 125, 319-327. [CrossRef]

39. Kumar, V.; Singh, S.; Upadhyay, N. Effects of organophosphate pesticides on siderophore producing soils microorganisms. Biocatal. Agric. Biotechnol. 2019, 21, 101359. [CrossRef]

40. Chovancova, S.; Neugschwandtner, R.; Ebrahimi, E.; Kaul, H. Effects of aqueous above-ground biomass extracts of cover crops on germination and seedlings of maize. Die Bodenkultur. Austrian J. Agric. Res. 2015, 66, 17-23.

41. Marcinkevičiene, A.; Kriauciuniene, Z.; Bogužas, V.; Velička, R. Allelopathic effects of cover crops on spring barley germination and establishment. J. Food Agric. Environ. 2013, 1, 684-688.

42. Gniazdowska, A.; Oracz, K.; Bogatek, R. Phytotoxic effects of sunflower (Helianthus annus L.) leaf extracts on germinating mustard (Sinapis alba L.) seeds. Allelopath. J. 2007, 19, 215-226.

43. Oracz, K.; Bailly, C.; Gniazdowska, A.; Côme, D.; Corbineau, F.; Bogatek, R. Induction of oxidative stress by sunflower phytotoxins in germinating mustard seeds. J. Chem. Ecol. 2007, 33, 251-264. [CrossRef] [PubMed]

44. Kupidłowska, E.; Gniazdowska, A.; Stepien, J.; Corbineau, F.; Vinel, D.; Skoczowski, A.; Janeczko, A.; Bogatek, R. Impact of sunflower (Helianthus annuus L.) extracts upon reserve mobilization and energy metabolism in germinating mustard (Sinapis alba L.) seeds. J. Chem. Ecol. 2006, 32, 2569-2583. [CrossRef] [PubMed]

45. Chovancova, S.; Neudert, L.; Winkler, J. The effect of three soil tillage treatments on weed infestation in forage maize. Acta Agrobot. 2019, 72, 1756. [CrossRef] 
46. Gawęda, D.; Haliniarz, M.; Bronowicka-Mielniczuk, U.; Łukasz, J. Weed Infestation and Health of the Soybean Crop Depending on Cropping System and Tillage Systém. Agriculture 2020, 10, 208. [CrossRef]

47. Winkler, J.; Trojan, V.; Hrubešová, V. Effects of the tillage technology and the forecrop on weeds in stands of winter wheat. Acta Univ. Agric. Silvic. Mendel. Brun. 2015, 63, 477-483. [CrossRef] 